\title{
World War II: bodies beyond the battlefield
}

\author{
Hannah Simpson (ㄷ, ', Megan Girdwood ${ }^{2}$
}

The destructive action of World War II extended far beyond the traditional battlefield arena, the more familiar trench-andno-man's-land zones that had typified World War I. This special issue investigates the impact of medical crisis and treatment on non-combatant bodies: civilian women, evacuated children, interned prisoners, spies and double agents, and, in the long aftermath of the war, medial patients affected by chronic physical injury, mental trauma, and changes to national healthcare provision and policy. In drawing attention to these multiple sites of nonbattlefield suffering and medical practice, this issue seeks to disrupt what we have termed here the 'single-body narrative' of the war's impact: the subsuming of all particularities of various bodily wartime experiences into the figure of the white male military body. The articles in this issue foreground the specificities of various lived bodily experiences of the war, rather than attempting to fuse them into any more easily assimilated but deceptively discrete narrative of single-body suffering.

One example of World War II destruction beyond the battlefield that has gone down in both military and literary history was the French town of Saint-Lô, which would acquire "the unenviable distinction of being the most heavily destroyed town in France' during the war. ${ }^{1}$ The civilians of Saint-Lô were spared the worst of the war's violence for most of the conflict, but in early June 1944 Allied bombers began a week-long series of air raids on the town, attempting to liberate it from German occupiers in order to open up crucial routes to and from the Normandy beaches. Over 1000 civilians were killed in the bombing, and more than $90 \%$ of the town's buildings were obliterated. The municipal hospital and the town's six pharmacies were also destroyed, leaving the town's doctor to perform amputations with a scavenged butcher's saw. ${ }^{2}$ In a humanitarian effort, the Irish Red Cross set up an emergency relief hospital in Saint-Lô in April 1945. Among the

\footnotetext{
${ }^{1}$ University of Oxford, Oxford, UK

${ }^{2}$ University of Edinburgh, Edinburgh, UK
}

Correspondence to Dr Hannah Simpson, London, UK; h.e.a.simpson@outlook.com volunteers who arrived to work there was Samuel Beckett, the Irish writer who, although still relatively unknown at the time, would go on to win the Nobel Prize for Literature in 1969. Between May and December that year, Beckett worked as storekeeper and interpreter for the Irish Red Cross hospital, and would detail the intense civilian suffering he saw there in a short piece of writing intended for broadcast on Irish radio, 'The Capital of the Ruins' (1946). Beckett describes a city 'bombed out of existence' and a desperate vision of 'humanity in ruins'. ${ }^{3}$ Alongside the mass of civilian air-raid injuries, he would witness the town's severe tuberculosis crisis, 'scabies and other diseases of the skin, the result no doubt of malnutrition', and new injuries caused by stillcollapsing buildings and children playing with the unexploded bombs left lying in the town's rubble. Scholars have increasingly begun to recognise the impact of Saint-Lô and its vision of mass civilian suffering on Beckett's later work, with its insistent focus on beleaguered human bodies, post-catastrophe landscapes and the seemingly endless labour of basic survival. ${ }^{4}$ The spectral reappearance of Saint-Lô's traumatised forms in Beckett's late twentieth-century experimental literature illustrates the historically and temporally diffuse nature of wartime bodily experience, which displaces the conventional battlefield as the singular marker of violence, injury and heroism.

This special issue, then, examines the broader, multibody impact of World War II beyond the battlefield's immediate moment and locus. Existing medical humanities scholarship, particularly within the history of medicine, has already generated valuable insights into World War II battlefield medical practice. Work by Tracey Shilcutt (2013), Mark Harrison (2004) and Albert E. Cowdrey (1994) has provided an impressively detailed survey of military medicine across the global theatres of war; Jane Brooks (2018) and Judith Barger (2013) have highlighted the vital presence of female medical practitioners on the front line, and Emily Mayhew (2018) has explored the development of reconstructive plastic surgery for wounded airmen in the aftermath of the conflict. Less closely examined, however, is the bodily suffering endured beyond World War II's front lines. This most total of modern wars had a bodily impact that extended far beyond its ostensible combat zones, reaching into civilian life with lethal persistence by dint of increased bomber plane capabilities, advanced chemical warfare, mass food blockades and mass prisoner-of-war incarceration. Marina MacKay rightly reminds us that World War II's 'insidious infiltration into all spheres of life', across the conflict's various home fronts and institutional structures, 'requires us to think more obliquely about whom war affects and how'.5 As part of this framework of diversified experience, the articles collected here draw together a wide range of disciplinary perspectives from within the medical humanities, and include both established and emerging voices in the field. By widening the boundaries of interdisciplinary consideration, and refusing to overly simplify the multiple ways in which the conflict damaged the human bodies it touched, this issue aims to retain a sense of the near-inconceivable scale of the mental and bodily suffering occasioned by World War II.

The articles in this issue also pay particular attention to how such scholarship might inform contemporary treatment and policy decisions regarding the physically or mentally war-wounded body. The broadened examination of war's impact beyond the battlefield has significant ongoing relevance to issues of contemporary healthcare provision and public policy, given modern warfare tactics such as the drone strike and the terror attack, ${ }^{6}$ in which civilian bodies and minds so often become intended or unintended casualties. It also speaks pertinently, indeed urgently, to the plight of migrant or refugee communities seeking relief from contemporary conflicts. The diversified medical humanities focus on World War II's bodily impact beyond the battlefield has the potential to offer invaluable strategies for navigating the civilian impact of modern warfare. We hope that the essays collected here will help enhance both professional and academic discourse in relation to war and conflict's continuing consequences for healthcare, public policy, and cultural understandings of injury and trauma today.

The first section of this issue examines specific challenges to and changes in medical practice occasioned by the war, beyond the immediate domain of battlefield treatment. In 'Special Operations: Plastic Surgery and Disguise: World War II', Roderick Bailey reads newly declassified 
British and American War Office files to reveal how Britain's Special Operations Executive employed plastic surgeons to alter the physical appearance of Allied spies set to enter occupied European territory, for reasons ranging from the need to disguise an agent's identity to concerns that the faces of Jewish agents conformed too closely to contemporary stereotype. Bailey explores how these historical cases illustrate the lengths to which Allied soldiers were prepared to go in order to ensure their survival and contribute to the Allied war effort, and engages with continuing debate over the ethics of bodily modification for the purposes of waging war. In 'The Case of Dr Masajiro Miyazaki: Japanese-Canadian Healthcare in World War II', Letitia Johnson investigates the experience of forcibly relocated Japanese-Canadian civilians when the Canadian government interned citizens of Japanese descent. Johnson explores the limitations in the healthcare provided to interned Nikkei citizens, and the means by which Japanese-Canadian medical professionals balanced adaptation and resistance in the struggle to continue their practiceinto which 'questions of race, creed, peace or war do not enter', Japanese-Canadian physician Dr Skimokura wrote-while interned during the war years. Johnson highlights the relevance of this underdiscussed history to ongoing contemporary concerns surrounding medical provision to mass migrant communities, and how healthcare provisions can become 'an expression of political power, prerogatives, and ideals' during times of conflict.

In the issue's third article, 'Waiting Machines: Anticipation, Threat, and Embodiment in the Lived Time of World War II', Laura Salisbury investigates how the civilian experience of 'waiting' under the threat of bodily annihilation-more often considered as a feature of wartime trench life-reconceptualised broader ideas of lived time for both medical personnel and civilian populations. Salisbury traces the representation of such waiting in Virginia Woolf's and Elizabeth Bowen's writing, alongside materials from the Mass Observation Archive and contemporary psychoanalytic accounts of time that developed from Wilfred Bion's work at the Northfield Military hospital in 1942, in order to explore how wartime waiting reshaped civilian and medical attitudes to experiences of durational temporality. Next, in "A Disastrous Blow": Psychiatric Risk, Social Indicators and Medical Authority in Abortion Reform in Post-War Britain', Sarah Crook tracks the influence of new wartime conceptions of psychiatric risk in the specific context of postwar abortion reform. Crook examines how World War II lent impetus to the creation of new models and explanatory frameworks of risk, encouraging a closer reading of the relationship between individual psychiatric disorder and social disarray. She reveals how these new conceptions of psychiatric risk informed debate around abortion reform in postwar Britain, drawing on new connections between social conditions and psychiatric vulnerability and the growing recognition of the medical and social domains as mutually constitutive in the aftermath of World War II. Jonathan Taylor continues this focus on large-scale policy practice in his article 'Child Evacuation and Bodily Investigations, England 1939-45', which examines the social work files compiled on the physical and mental well-being of the 8000 children evacuated to the Lake District in northern England during the war. Taylor analyses how the children's embodied reactions to evacuation influenced their relationships with their host families, and how the medical and social practitioners' reading of these children's symptoms were often refracted through categories of class and gender. Both fields of investigation, Taylor reminds us, have particular pertinence to the British government's recent move to accept responsibility for hundreds of unaccompanied refugee children. Lastly, Sue Vice's article 'Dementia as Cultural Metaphor in Holocaust Narratives' focuses on contemporary psychoanalytical and literary response to cases of dementia in Holocaust survivors, and the associated issue of preserving Holocaust memory. Building on clinical disagreement as to whether extreme trauma is more likely to increase or decrease an individual's predisposition to dementia, Vice explores how the common association of the Holocaust witness with the politics of remembrance renders the idea of the survivor with dementia so unsettling-particularly in the context of anxieties generated by the impending end of the current 'era of the witness', as the Holocaust steadily turns from an event in living memory to one of purely historical record. Vice analyses literary and filmic narratives that treat the figure of the dementia-stricken Holocaust survivor, including Michael Lavigne's Not Me (2005), Josh Appignanesi's Ex Memoria (2006), Lauren Grossman's The Golden Peacock (2015) and Atom Egoyan's Remember (2015), emphasising how these depictions tend to focus attention on the anxiety of the onlooker, rather than on the subjective experience of the Holocaust survivors themselves.
This issue concludes with two commentaries from leading voices in the field of medical history. In 'Serving the Nation, Serving the People: Echoes of War in the Early NHS', Roberta Bivins describes how, overburdened in the war's aftermath, the National Health Service (NHS) was rhetorically constructed as both a reward for wartime service, and as a site of continued patriotic labour. Civilians could continue to 'serve their country' by joining the NHS's workforce, and by taking self-preventative care of their own bodies in order to reduce demand on the already overstretched service. Bivins thus emphasises the postwar NHS ias a postwar 'reward' for British soldiers and civilians, and a site of the persistence of war's demands on civilians and civilian bodies beyond the battlefield's geographical and temporal scope. Finally, and drawing the issue to a fitting close, in 'A Higher Form of Listening' Emily Mayhew examines how this issue's interdisciplinary range reflects the generative multidisciplinary scope in the developing field of medical humanities. Mayhew argues that a closely detailed and empathic interdisciplinary analysis of physical and mental injury can offer additional historical and cultural resources to medical practitioners, thus broadening potential patient treatment options beyond institutional and disciplinary boundaries.

Funding The authors have not declared a specific grant for this research from any funding agency in the public, commercial or not-for-profit sectors.

Competing interests None declared.

Patient consent for publication Not required.

Provenance and peer review Not commissioned; internally peer reviewed.

(C) Author(s) (or their employer(s)) 2020. No commercial re-use. See rights and permissions. Published by BMJ.

$$
\text { (A) Check for updates }
$$

To cite Simpson H, Girdwood M. Med Humanit 2020;46:93-95.

Accepted 16 March 2020

Med Humanit 2020;46:93-95. doi:10.1136/ medhum-2020-011891

\section{ORCID iD}

Hannah Simpson http://orcid.org/0000-0002-25447787

\section{NOTES}

1. Phyliss Gaffney (1999), Healing amid the Ruins: The Irish Hospital at Saint-Lô, 1945-46 (Dublin: A\&A Farmar, 1999), 1.

2. Gaffney, Healing amid the Ruins, 8 .

3. Samuel Beckett (1995), "The Capital of the Ruins," in Samuel Beckett: The Complete Short Prose 1929-1989, ed. S. E. Gontarski (New York: Grove Press, 1995), 277, 
276

4. See, for example, Rhys Tranter (2018), Beckett's Late Stage: Trauma, Language, and Subjectivity (Stuttgart: Ibidem, 2018); Laura Salisbury, Samuel Beckett: Laughing Matters, Comic Timing (Edinburgh: Edinburgh University Press, 2012); Linda Ben-Zvi (2011), "Beckett and Disgust: The Body as Laughing Matter," Modernism/Modernity 18, no. 4 (2011): 681-98; and Andrew Gibson (2010), Samuel Beckett (London: Reaktion Books, 2010).

5. Marina MacKay (2009), "Introduction," in The Cambridge Companion to World War II, ed. Marina MacKay (Cambridge: Cambridge University Press, 2009), 6-7.

6. See, respectively, Parks and Kaplan (2017), Life in the Age of Drone Warfare (Durham: Duke University Press, 2017), and Peter R. Old Neumann (2009), Old and New Terrorism: Late Modernity, Globalization and the Transformation of Political Violence (Cambridge: Polity Press, 2009).

\section{BIBLIOGRAPHY}

Barger, Judith. Beyond the Call of Duty: Army Flight Nursing in World War II. Kent, Ohio: Kent State University Press, 2013.

Beckett, Samuel. "The Capital of the Ruins." In Samuel Beckett: The Complete Short Prose 1929-1989, edited byS. E Gontarski, 275-8. New York: Grove Press, 1995.

Ben-Zvi, Linda. "Beckett and Disgust: The Body as "Laughing Matter"." Modernism/modernity 18, no. 4 (2011): 681-98.

Brooks, Jane. Negotiating Nursing: British Army Sisters and Soldiers in the Second World War. Oxford University Press: Oxford, 2018.

Cowdrey, Albert E. Fighting for Life: American Military Medicine in World War II. New York: Free Press, 1994.

Gaffney, Phyliss. Healing amid the Ruins: The Irish Hospital at Saint-Lô, 1945-46. Dublin: A\&A Farmar, 1999.

Gibson, Andrew. Samuel Beckett. London: Reaktion Books, 2010.
Harrison, Mark. Medicine and Victory: British Military Medicine in the Second World War. Oxford University Press: Oxford, 2004.

Mayhew, Emily. The Guinea Pig Club: Archibald Mclndoe, the Royal Air Force and the Reconstruction of Warriors. London: Greenhill, 2018.

Neumann, Peter R. Old. New Terrorism: Late Modernity, Globalization and the Transformation of Political Violence. Cambridge: Polity Press, 2009.

Lisa Parks, and Caren Kaplan. eds. Life in the Age of Drone Warfare. Durham: Duke University Press, 2017.

MacKay, Marina. "Introduction." In The Cambridge Companion to World War II, edited byMarina Mackay. Cambridge: Cambridge University Press, 2009. 1-10

Salisbury, Laura. Samuel Beckett: Laughing Matters, Comic Timing. Edinburgh: Edinburgh University Press, 2012.

Shilcutt, Tracy. Infantry Combat Medics in Europe, 1944-45. Basingstoke: Palgrave Macmillan, 2013.

Tranter, Rhys. Beckett's Late Stage: Trauma, Language, and Subjectivity. Stuttgart: Ibidem, 2018. 